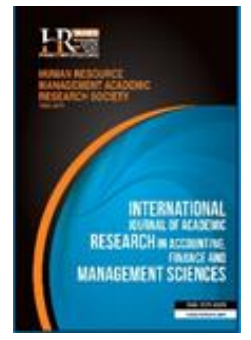

International Journal of Academic Research in Accounting, Finance and Management Sciences

Vol. 9, No.4, October 2019, pp. 118-125

E-ISSN: 2225-8329, P-ISSN: 2308-0337

(C) 2019 HRMARS

www.hrmars.com

To cite this article: Ofurum, C. N., Ogunyemi, O. J., Amobi, B. N., Okonya, B. E. (2019). Social Responsibility Costs and

Financial Performance in Manufacturing Companies in Nigeria: A Panel Research Design, International Journal of

Academic Research in Accounting, Finance and Management Sciences 9 (4): 118-125

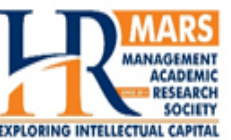

$\frac{1}{\text { EXPLORING INTELECTUAL CAPTTAL }}$

www.hrmars.com

ISSN: 2225-8329

http://dx.doi.org/10.6007/IJARAFMS/v9-i4/6752 (DOI: 10.6007/IJARAFMS/v9-i4/6752)

\title{
Social Responsibility Costs and Financial Performance in Manufacturing Companies in Nigeria: A Panel Research Design
}

\author{
Chijioke N. Ofurum ${ }^{1}$, Odunayo J. Ogunyemi ${ }^{2}$, \\ Blessing N. Amobi ${ }^{3}$, Bossco E. Okonya ${ }^{4}$ \\ ${ }^{1,3}$ Department of Accounting, University of Nigeria, Enugu Campus, Enugu, Nigeria, \\ E-mail: cjofurum@gmail.com (Corresponding author) \\ ${ }^{2,4}$ Department of Accounting, Imo State University, Owerri, Nigeria
}

\begin{tabular}{|c|c|c|}
\hline Abstract & \multicolumn{2}{|c|}{$\begin{array}{l}\text { This paper ascertained the relationship between social responsibility cost (SRC) and financial performance of } \\
\text { manufacturing companies listed on Nigeria stock exchange. The study employed a panel research design with } \\
\text { a sample of three manufacturing companies in Nigeria namely: Nigeria Breweries PIc, Dangote Cement PIc } \\
\text { and Floor Mills Nigeria. Secondary data sources were utilized for the study using the firms' annual report. } \\
\text { Social responsibility cost was proxied with the companies' voluntary donations to the society while profit } \\
\text { after tax and return on assets where used as measures of financial performance. Breusch-Pagan LM and } \\
\text { Pesaran scaled LM cross-sectional dependency test and Jarque-BeraTest of normality were the diagnostic } \\
\text { tests employed to certify the suitability of the data for panel regression. Pooled Panel Least Squares } \\
\text { regression of used as the method of data analysis using Eviews 9. The study found that social responsibility } \\
\text { cost has neutral effect on profit after tax and return on assets after controlling for firms' size. }\end{array}$} \\
\hline Key words & \multicolumn{2}{|c|}{ Social Responsibility Cost, Manufacturing Companies, Dependency Test, Panel Regression } \\
\hline Received: & 09 Dec 2019 & (C) The Authors 2019 \\
\hline Revised: & 22 Dec 2019 & Published by Human Resource Management Academic Research Society (www.hrmars.com) \\
\hline $\begin{array}{l}\text { Accepted: } \\
\text { blished Online: }\end{array}$ & $\begin{array}{l}27 \text { Dec } 2019 \\
04 \text { Jan } 2020\end{array}$ & $\begin{array}{l}\text { This article is published under the Creative Commons Attribution (CC BY } 4.0 \text { ) license. Anyone may } \\
\text { reproduce, distribute, translate and create derivative works of this article (for both commercial and } \\
\text { non-commercial purposes), subject to full attribution to the original publication and authors. The full } \\
\text { terms of this license may be seen at: http://creativecommons.org/licences/by/4.0/legalcode }\end{array}$ \\
\hline
\end{tabular}

\section{Introduction}

The effect of corporate social responsibility costs on financial performance is becoming all the time more crucial to a broad range of corporate stakeholders; notwithstanding the fact that companies investment in social responsibility activities have not been easy to manage. It is believed to be one the tools that organizations must implement to ensure and main a peaceful business environment. This therefore suggests that the corporate social responsibilities of the firm is not limited to internal stakeholders such as the employees, managers, the board of directors, investors but are also covers individuals not inside a business itself but who are interested in or are impacted by its performance such as: regulators, consumers, investors, suppliers, communities etc.

In Nigeria, corporate social responsibility is basically carried out by Deposit money banks, manufacturing firms, oil \& gas industries and so on. The CSR activities of these industries include provision of pipe borne water, provision of electricity poles and transformers, expansion of school buildings and construction of new ones, road maintenance, health care services, sponsoring of tournaments, quiz and debates, issuing of scholarships to the less privileged and down-syndrome and many others. 
Whereas social responsibility cost has been on the increase from year to year, there is no consensus from results of previous empirical studies on the nature of relationship social responsibility cost has with profitability. While researchers such as Handayani et al. (2017), Amole et al. (2012) and others argued that CSR has a positive and significant impact on financial performance of firms, Ashnie (2011) and others argued that a negative and significant relationship exist between CSR and financial performance. Against these discrepancies, the researchers wish to empirically examine the relationship between the two variables using manufacturing companies listed in Nigeria stock exchange.

\section{Literature review}

\subsection{Social Responsibility}

Palmer (1995) avers that social responsibility is a duty every individual has to perform so as to maintain a balance between the economy and the ecosystems. In the study, the concept of social responsibility shall be discussed from an organization perspective which is otherwise known as corporate social responsibility. Corporate social responsibility is an initiative of the firm to assume responsibility for the firm's effects on environmental and social wellbeing. Odetayo et al. (2014) state that Corporate social responsibility also called corporate conscience or corporate social performance are duties performed by organizations to the society in which they operate, such as protection of the environment, provision of social amenities, health and safety, and so on.

According to Holme and Watts (2002) "Corporate Social Responsibility is the continuing commitment by business to behave ethically and contribute to economic development while improving the quality of life of the workforce and their families as well as of the local community and society at large". The term also called corporate sustainability, sustainable business, corporate conscience, corporate citizenship or responsible business generally applies to efforts that go beyond what may be required by regulators or environmental protection groups. World Business Council for Sustainable Development (WBSCD) (1999) defines corporate social responsibility as "the continuing commitment by business to behave ethically and contribute to economic development while improving the quality of life of the workforce and their families as well as that of the local community and society at large.

Adeyanju (2012) believe that corporate social responsibility means that a corporation should be held accountable for any of its actions that affect people, communities, and its environment. It suggests that harmful business impacts on society should be put to check, if possible. The European Union (2001) Green Paper defines corporate social responsibility as "a concept whereby companies integrate social and environmental concerns in their business operations and in their interaction with their stakeholders on a voluntary basis. Sheehy (2012) argued that while it has been considered a form of corporate self-regulation for some time, over the last decade it has moved considerably from voluntary decisions at the level of individual organizations, to mandatory schemes at regional, national and even transnational levels. With some models, a firm's adoption of CSR goes above what regulatory requirements stipulate, and engages in "activities that appear to advance some social good, over and above the interests of the firm and that which is required by law".

However, it is worthy to not that an organization may choose to comply with the law, fail to comply, or go beyond the law for some special reasons. The choices of 'complying' with the law, failing to comply, and 'going beyond' are three distinct strategic organizational choices. While in many areas such as environmental or labor regulations, employers may choose to comply with the law, or go beyond the law, other organizations may choose to flout the law (Wikipedia, 2019).

\subsection{Social Responsibility Cost of Manufacturing Companies in Nigeria}

While social responsibility of an organization looks at the obligations or duties expected to be carried out in the society by the firm, social responsibility cost simply means the actual expenditure made in the course of carrying out those duties. On yearly basis, some manufacturing companies do not just disclosed their corporate social responsibility ethics and policies but also quantify and report the monetary value of each of their social responsibility activities in their annual report.

For example, Nigerian Breweries Plc in 2012 made a total expenditure of N81,674,450 as a way of showing their support to the affairs of the society. The beneficiaries of this donation were: African-Artistes 
Foundation (N29,000,000), Farafina Trust $(\mathrm{N} 25,000,000)$, National Sports festival $(\mathrm{N} 10,000,000)$, Beyond the School Project $(\mathrm{N} 8,873,300)$, Nigerian Economic Summit Group (N2,500,000), The Netherlands International School Lagos (N2,500,000), Nigeria Employers' Consultative Association $(\mathrm{N} 3,000,000)$, National Agency for Food and Drug Administration and Control (N801,150) (Nigeria Breweries Plc, 2012:12).

In 2016, Dangote Cement incurred a social responsibility cost of N474.4 billion both within and outside Nigeria. Countries that benefited other than Nigeria were: Congo, Ethiopia, South Africa, Tanzania, Zambia and Cameroun. In Congo, only one donation was made to Individual villagers and community amounting to N158 million. In Ethiopia, Donation for elderly and mentally disabled people wereN2,338 million, Dugba Police received N702 million and ChanchoBirate School got N566 million were the major donations made. In South Africa, Aluminium sheets for hospital corners and doors - Lichtenburg was N117.6 million while Advert Hoerskool Lichtenburg newsletter received N117.9 million, other six donations mostly to primary and high schools were below 100 million. In Tanzania, Masasi Leprosy Centre received N211.5 million while N8.9 billion was spent on School desks, In Zambia, Zambia National Association of the Physically Handicapped got N38.2 million, Donation for fertilizer to villagers amounted to N362.3 million and Cement donated to the chief for the Community amounted to N607.1 million. In Cameroun, Njoya Foundation got N8,784 million, Ngondo Celebration giot N4,392 million, Chefferie of Sodiko received $\mathrm{N} 1,233.3$ million.

In Senegal, several donations were made to support Ramadan (N5,248.4 million), Mosque and Church Construction (N2123.5 million), Pilgrimage donation (N22.7 billion), Tabaski sheep donation for the villagers (N1.9 billion), Sponsorship for the Senegalese Union of Traders (Unacois) (N2.7 billion), Sponsorship for the Touba Magal religious events (N2.2 billion), Sponsorship for the Mines Forum (Sim) (N3 million), Sponsorship of local movie - La GargotteTfm (N2.2 million) etc. in Nigeria, 57 projects were donated to with 5 donations amounting to 20 billion or above each. This projects were: Theirworld (N115.7 billion), Sponsorship of Police Weeks Games 2016 (N20 billion), Ogun State Investors' Forum (N25 billion), Manufacturers' Association of Nigeria (N20 billion) and The Nigerian Economic Summit (N2O billion). (Dangote Cement, 2016). The thrust of this work is to examine the relationship between these social responsibility cost and the firms performance.

According to Nigeria Brewwries (2017) a total of N76.9 million naira was used as social responsibility cost for the year. The amount was distributed as follows: borehole project for police college at Jos N5.2 million, refurbishment/equipping of kudenda primary health center N5.1 million, streetlight project for Ameke road, Umuezeani, Enugu N5.4 million, scholarship scheme for Imagbon community indigenes N1.1 million, solar powered borehole for Alalubosa community, Ibadan N6 million, medical equipment and drug donation Alaka Health care center N9.2 million, Lagos international poetry competition N6 million, federal road safety commission campaign N12.9 million, transformer for Ota brewery host community N4.8 million, sponsorship of Kaduna state investment forum N10.5 million and renovation of Nigeria Immigration service clinic, Ikoyi N10.7 million. The focus of this study is to examine the relationship between these social responsibility cost and financial performance of the firms.

\subsection{Theoretical Framework}

\subsubsection{The social contract theory}

This theory which was pioneered by Hobbes (1651) has been one of the most dominant theories within moral and political theory throughout the history of the modern West. The theory states that persons' moral and/or political obligations are dependent upon a contract or agreement among them to form the society in which they live. The emphasis of theory is how to relate a corporation to society. This is the point that brings up the ethical or moral duties of corporations. According to Dillbeck (undated) 'some of the earliest evidence of social contract theory can be found in Hebrew scripture which talks about a covenant between humankind and God, establishing a theocratic state in which humankind has freedom within limits set by God in order to institute harmony in creation'. This implies that for two parties to cohabit peacefully there should be a mutual implicit or explicit understanding between the two parties. In this case, the corporation is one party and the society who owns the environment on which the corporation operates is another party. It is therefore expected of the corporation to act in a way and manner that will not violate the existing norms and values of the society but adds value to the environment and society at 
large in which they operate. The basic argument in this theory is that individual or corporate should not fail to adhere to the rules and regulations of the society or environment that gave them room for their existence.

\subsection{Empirical review}

The relationship between corporate social responsibility and firms' performance has been long debated by various researchers both within and outside the country with mixed results.

For instance, Handayani et al. (2017) in their study "The effects of corporate social responsibility on manufacturing industry performance: the mediating role of social collaboration and green innovation" examined the effect of corporate social responsibility on the manufacturing firms' performance. The study covers a total population of 439 manufacturing firms in Central Java. A survey research design was adopted and a well-structured questionnaire on theirs CSR activities and financial performance were sent to the top managers of the firms. The study concludes that corporate social responsibility has a positive and significant relationship with manufacturing firms' performance.

Ashnie (2011) examined the existence of a trade-off between social responsibility and corporate financial performance (profitability). Employing a panel research design, the study sampled 80 firms which were divided into 60 conventional investors and 20 social investors in European and North American between the period 2000 to 2009, the researcher used a dummy variable (1) for an investor that is socially responsible and (0) for an investor that is not socially responsible as a proxy for CSR while ROA and ROIC are proxies for financial performance after controlling for firms' size, risk, growth and age. Pooled ordinary least squares (OLS) regression was employed to estimate the impact of CSR on firms' financial performance. The study established that social responsibility is significant and negatively related to corporate financial performance, supporting the theory that there is a trade-off. The study concludes that socially responsible investors are less profitable than their conventional counterparts. Further findings revealed that the control variables, size and risk appear to be significantly related to corporate financial performance in most cases,

Olayinka and Temitope (2011) in their study "Corporate Social Responsibility and Financial Performance in Developing Economies: The Nigerian Experience" examined the impact of CSR activities on financial performance measured with Return on Equity (ROE) and Return on Assets (ROA). Their research design was content analysis design and data were sourced from 2007 published annual reports of the firms. Both Pearson correlation and multiple linear regression statistical methods where adopted to analyze their data. The study concludes that CSR has a positive and significant relationship with the financial performance measures.

Amole et al. (2012) examined the relationship between CSR and banks profit using ordinary least square (OLS) model of regression. Analysis found out that for every unit increment in the CSR expenditure, there will be $95 \%$ increase in the profit after tax of the bank. The study concludes that there is positive relationship between banks CSR activities and profitability, stating the need for banks to demonstrate high level of commitment to corporate social responsibility based on stakeholders theory in order to enhance their profitability in the long run. Ginnarakis and Theotokas (2011) assessed corporate social responsibility of 112 companies that adopted the Global Reporting Initiative from 2007 to 2010 so as to determine the effects of the financial crisis on corporate social responsibility performance. The study employed Wilcoxon signed-rank-sum test as a method of analysis. Findings revealed that increase in CSR significantly increases business performance.

\section{Methodology of research}

\subsection{Nature and Sources of Data}

Secondary sources of data were used for the study. The data were sourced from the annual report of three manufacturing companies vis: Nigeria Breweries plc, Floor Mills Nigeria plc, and Dangote Cement plc. These companies were selected based on the annual reporting of their social responsibility cost in figures unlike others that mention and describe the extent of the social responsibilities carried without its Naira equivalents in the annual report. All social donations made by the companies were used as social responsibility cost of the firm (SRC) while profit after tax and return on assets were used as financial performances indexes. Total Assets and Total Equity were used as control variables in the study. Due to the 
fact that most firms did not adopt the pattern of reporting their social responsibility expenditures in figures early enough, for instance Nigeria Breweries started reporting their expenditures in 2007, Floor Mills Nigeria started in 2012, while Dangote Cement started in 2011, thus the time series nature of the data was unbalance.

\subsection{Model specification}

The functional relation between social responsibility cost and manufacturing sector financial performance can be stated as:

$$
\begin{aligned}
& P A T=f(S R C, A S S E T, E Q U I T Y) \ldots e q 1 \\
& R O A=f(S R C, A S S E T, E Q U I T Y) \ldots e q 2
\end{aligned}
$$

Where:

SRC - Social Responsibility Cost

PAT - Profit after Tax

ROA - Return on Assets

Assets - Total Assets (control variable)

Equity - Total Equity (control variable)

The model can be stated econometrically as

$$
\begin{aligned}
& P A T_{i t}=B_{0}+B_{1} S R C_{i t}+B_{2} A_{s s e t}{ }_{i t}+B_{3} E_{\text {Equity }}+{ }_{i t}+\mu_{i t} \ldots . . \text { eq } 3 \\
& R O A_{i t}=B_{0}+B_{1} S R C_{i t}+B_{2} \text { Asset }_{i t}+B_{3} \text { Equity }_{i t}+\mu_{i t} \ldots \text { eq } 4
\end{aligned}
$$

Where the subscripts $i$ and $t$ follow the statistical units (companies) over time.

$\beta_{0}=$ Constant term

$\beta_{1} . \beta_{3}=$ Parameters to be estimated (coefficients)

$\mu=$ Error term.

$\mathrm{t}=$ the $\mathrm{t}$-th year (time series annual data).

\section{Results and Discussions}

This section presents results of the models specified above and relevant findings from the analysis.

\subsection{Dependence Test}

This test was carried out to ensure that the disturbances in panel data models are cross sectionally independent. This is necessary because the presence of cross sectional dependence in the residual can give

\begin{tabular}{|c|c|c|c|}
\hline \multicolumn{4}{|c|}{$\begin{array}{l}\text { Null hypothesis: No cross-section dependence (correlation) in residuals } \\
\text { Test employs centered correlations computed from pairwise samples }\end{array}$} \\
\hline Test & Statistic & d.f. & Prob. \\
\hline Breusch-Pagan LM & 3.566734 & 3 & 0.3122 \\
\hline Pesaran scaled LM & -0.993377 & & 0.3205 \\
\hline Pesaran CD & 1.130148 & & 0.2584 \\
\hline
\end{tabular}
rise to invalid test statistics. The study employed Breusch-Pagan (1980) LM and Pesaran (2004) Scaled LM dependence test to ascertain the presence of cross sectional dependence in the residuals.

Table 1. Residual Cross-Section Dependence Test

Both Breusch-Pagan LM and Pesaran scaled LM test accepts the null hypothesis at 0.05 critical level that there is no cross sectional dependence in the residual, hence the panel data is suitable for regression.

Test or normality was carried out to determine if a data set had a normal distribution. It describes the aggregated averages of the mean, median and standard deviation which are measures of spread and variation, skewness which looks at the symmetry and Kurtosis which looks at the centrality of the peak. The skewness value is 0.04 which indicates that the distribution is approximately symmetric while the Kurtosis 
value of 3.7 shows that the distribution is leptokurtic bordering mesokurtic. The overall Jarque-Bera statistics of 0.66 shows that the data is normally distributed.

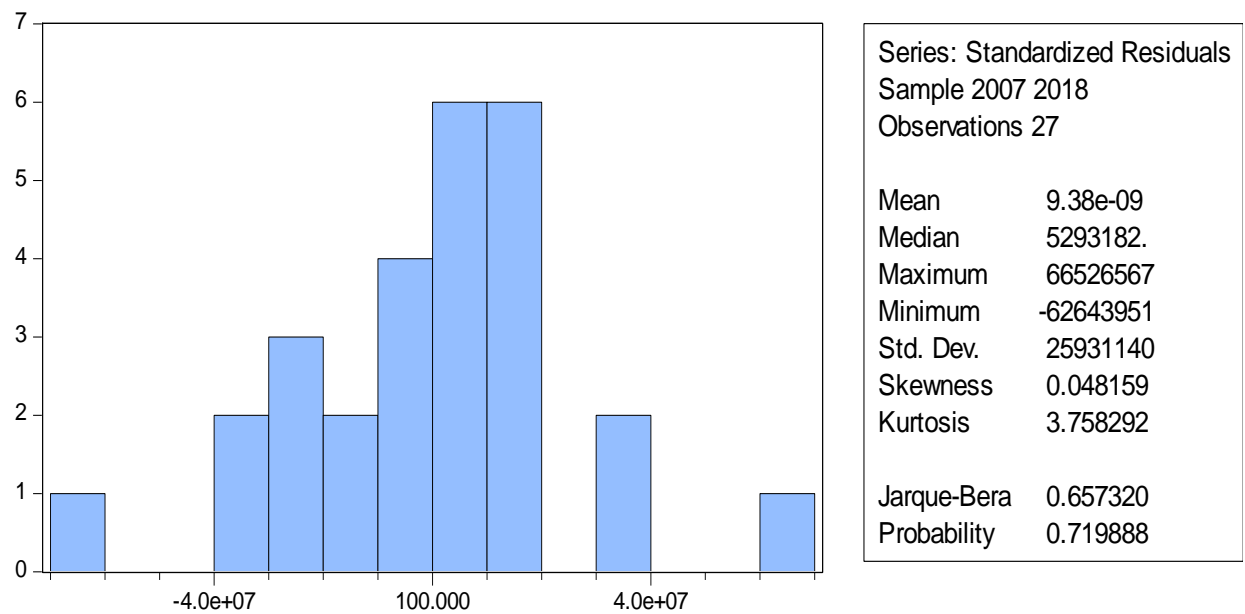

Figure 1. Test of Normality

Table 2. Panel Least Squares result for Model One

Dependent Variable: PAT

Method: Panel Least Squares

Total panel (unbalanced) observations: 27

\begin{tabular}{lllll}
\hline \hline Variable & Coefficient & Std. Error & t-Statistic & Prob. \\
\hline \hline SRC & 27.11583 & 19.06623 & 1.422191 & 0.1684 \\
ASSET & 0.297910 & 0.025930 & 11.48907 & 0.0000 \\
EQUITY & -0.656626 & 0.132877 & -4.941626 & 0.0001 \\
C & -25849.27 & 8803070. & -0.002936 & 0.9977 \\
\hline \hline R-squared & 0.949783 & Mean dependent var & 85801991 \\
Adjusted R-squared & 0.943234 & S.D. dependent var & $1.16 \mathrm{E}+08$ \\
F-statistic & 145.0055 & Durbin-Watson stat & 2.275199 \\
Prob(F-statistic) & 0.000000 & & & \\
\hline \hline
\end{tabular}

The table above shows the result for the first model. As presented above, analysis revealed that all the explanatory variables explained a significant proportion of variance in the firms' profit. $R^{2}=.94, F=$ $145.0, p<.001$.The R-square (.94) indicates 'a good fit' showing that 94 per cent of the variations in Profit are explained by the combined effect of variations in the explanatory variables. The F-statistics (145) with Prob. value less than 0.001 confirms further that the explanatory variables are jointly and statistically significant in explaining the variations in the firms' profit. On the contribution of social responsibility cost to the firms' profit, analysis showed that it has no significant impact on firms' profitability rather the size of the bank in terms of total asset determines more of the variations in the firms' profit. SRC has a coefficient of 27.1 with a probability value of 0.17 .

Table 3. Panel Least Squares result for Model Two

Dependent Variable: ROA

Method: Panel Least Squares

Total panel (unbalanced) observations: 27

\begin{tabular}{|c|c|c|c|c|}
\hline Variable & Coefficient & Std. Error & t-Statistic & Prob. \\
\hline SRC & 4.43E-06 & $1.03 \mathrm{E}-05$ & 0.429933 & 0.6712 \\
\hline ASSET & $-1.39 \mathrm{E}-08$ & $1.40 \mathrm{E}-08$ & -0.992282 & 0.3314 \\
\hline EQUITY & $-3.07 E-07$ & $7.18 \mathrm{E}-08$ & -4.271515 & 0.0003 \\
\hline
\end{tabular}




\begin{tabular}{lcccc} 
C & 40.74776 & 4.755039 & 8.569386 & 0.0000 \\
\hline \hline R-squared & 0.520783 & Mean dependent var & 28.06345 \\
Adjusted R-squared & 0.458277 & S.D. dependent var & 20.23371 \\
F-statistic & 8.331665 & Durbin-Watson stat & 0.605824 \\
Prob(F-statistic) & 0.000626 & & \\
\hline \hline
\end{tabular}

The table above shows the panel least square result for ROA model. Findings shows that the explanatory variables made an average contributions to the variations in the firms $\operatorname{ROA}\left(R^{2}=.52, F=8.33, p\right.$ $<.001$ ). The R-square .52 indicates that 52 per cent of the variations in ROA are explained by the combined effect of variations in the explanatory variables. The F-statistics of 8.3 with Prob. value less than 0.001 confirms further that the explanatory variables are jointly and statistically significant in explaining the variations in the firms ROA. On the contribution of social responsibility cost to the firms' ROA, analysis showed that it has no significant impact on firms' return on assets. SRC has a coefficient of 0.0000044 with a probability value of 0.67 .

\section{Conclusions}

The issue of the relationship between social responsibility cost and performance of firms has been long debated for decades since the work of Bragdon and Marlin (1972) and Moskowitz (1972) which were regarded as the first study that empirically examined the relationship between corporate social responsibility and financial performance. This work has tried to narrow down this relationship in the manufacturing sector contest, using firms listed on Nigeria Stock Exchange between 2007 and 2017. The study found a neutral relationship between profit after tax, return on assets and social responsibility cost; while the relationship between corporate social responsibility and return an asset were found to be neutral. Against the findings above, we recommend that manufacturing firms who do not have cash readily available to carry out social responsibilities should consider using their products in some cases to show their support to the community, considering the fact that manufacturing firms tie down capital in different stages of production, and always need cash to continue operations.

\section{References}

1. Adeyanju, O. D. (2012). An Assessment of the Impact of Corporate Social Responsibility on Nigerian Society: The Examples and Banking and Communication Industries. Universal Journal of Marketing and Business Research, 1(1), $17-43$.

2. Amole, B. B., Adebiyi, S. O., \& Awodeji, A. M. (2012). Corporate Social Responsibility and Profitability of Nigeria Banks - A Causal Relationship. Research Journal of Finance and Accounting, 3(1): 6 18.

3. Ashnie, P. (2011). Is there a trade-off between social responsibility and financial performance (Master's Thesis). Erasmus school of economics.

4. Bragdon, J. H., (Jr), \& Marlin, J. A. T. (1972). Is pollution profitable? Risk Management, 19: 9-18.

5. Breusch, T., \& Pagan, A. (1980). The Lagrange Multiplier test and its application to model specification in Econometrics. Review of Economic Studies, 47, 239-254.

6. Corporate Social Responsibility. (2019). Retrieved September 8, 2019, from Wikipedia: https://en.wikipedia.org/wiki/Corporate_social_responsibility

7. Dillbeck, B. (undated). Social Contract. Retrieved from: https://www.learningtogive.org /resources/social-contract

8. European Commission. (2001). Promoting a European framework for corporate social responsibility. Brussels. EU Commission Green Paper. Retrieved from: http//www.ilo.org/wcmsp5/groups/ public/dgreports/integration/documents/publication/wcms_079130.pd.

9. Ginnarakis, G., \& Theotokas, I. (2011). The effect of financial crisis in Corporate Social Responsibility Performance. International Journal of Marketing Studies, 3, 2-10. 
10.Handayani, R., Wahyudi, S., \& Suharnomo, S. (2017). The effects of corporate social responsibility on manufacturing industry performance: the mediating role of social collaboration and green innovation. Business: Theory and Practice. 18(1):152-159. DOI: 10.3846/btp.2017.016.

11.Holme, L., \& Watts, R. (2002). Corporate Social Responsibility: Making Good Business Sense". World Business Council for Sustainable Development. pp 1-31

12. Moskowitz, M. (1972). Choosing Socially Responsible Stocks. Business and Society Review, 1: 7175.

13. Nigeria Breweries Plc (2017). Annual Report and Accounts. Retrieved from: https://nbplc.com

14.Odetayo, T.A., Adeyemi, A.Z., \& Sajuyigbe, A.S. (2014). "Impact of Corporate Social Responsibility of Nigeria Banks". International Journal of Academic Research in Business and Social Sciences. 4(8): 252263.

15.Olayinka, M. U., \& Temitope, O. F. (2011). Corporate Social Responsibility and financial performance in developing Economies-The Nigerian Experience. New Orleans, New Orleans International Academic Conference, 815-824.

16.Palmer, K. (1995). Tightening Environmental Standards: The Benefit-Cost or the No-Cost Paradigm. The Journal of Economic Perspectives. 9 (4): 119-132. doi:10.1257/jep.9.4.119. JSTOR 2138393

17.Pesaran, M. H. (2004). General Diagnostic Tests for Cross Section Dependence in Panels. University of Cambridge, Faculty of Economics, Cambridge Working Papers in Economics No. 0435

18. Sheehy, B. (2012). Understanding CSR: An Empirical Study of Private Regulation. Monash University Law Review. 38: 103-127.

19.WBCSD. (1999). Corporate Social Responsibility. Meeting Changing Expectations. ConchesGeneva. Retrieved from www.wbcsd.org. 